\title{
New records of Monstrilloida Sars, 1901 (Crustacea: Copepoda) from Rio Grande do Norte (northeastern coast of Brazil)
}

\author{
Cristina de Oliveira Dias ${ }^{1,3}$, Guilherme Fulgêncio de Medeiros $^{2}$ \& Sérgio Luiz Costa Bonecker ${ }^{1}$ \\ ${ }^{1}$ Laboratório Integrado de Zooplâncton e Ictioplâncton, Departamento de Zoologia, Instituto de Biologia, \\ Universidade Federal do Rio de Janeiro - UFRJ, \\ Prédio do CCS, Bloco A, Ilha do Fundão, CEP 21941-590, Rio de Janeiro, RJ, Brazil \\ ${ }^{2}$ Departamento de Oceanografia e Limnologia, Centro de Biociências, \\ Universidade Federal do Rio Grande do Norte - UFRN, \\ Praia de Mãe Luiza, s/n, Via Costeira, CEP 59014-100, Natal, RN, Brazil \\ ${ }^{3}$ Corresponding author: Cristina de Oliveira Dias, e-mail: crcldias@biologia.ufrj.br
}

DIAS, C.O., MEDEIROS, G.F. \& BONECKER, S.L.C. 2008. New records of Monstrilloida Sars, 1901 (Crustacea: Copepoda) from the Rio Grande do Norte (northeastern coast of Brazil). Biota Neotrop. 8(2): http://www.biotaneotropica.org.br/v8n2/en/abstract?short-communication+bn01508022008.

\begin{abstract}
During a series of zooplankton surveys carried out during 1984, off the south coast of the state of Rio Grande do Norte, Brazil, several species of monstrilloids were present in the samples. A total of 50 individuals of monstrilloid copepods were collected. These belong to four species (Monstrilla brasiliensis Suárez-Morales \& Dias, Cymbasoma cf. longispinosum, Cymbasoma cf. rigidum, and Cymbasoma gracilis Gurney). The taxonomic complexes formed by the species $C$. cf. longispinosum and $C$. cf. rigidum in Brazilian waters are discussed. The lengths of the specimens are provided in order to contribute to studies and revisions of the specimens belonging to these species-complexes. The species Monstrilla brasiliensis is recorded for the first time in the Rio Grande do Norte coastal region, thus expanding its geographical range in the Brazilian northeastern coast. The results presented herein increase to four the number of species of Monstrilloida known from off Rio Grande do Norte state.
\end{abstract}

Keywords: zooplankton, copepods, southwest atlantic, brazilian coast, Monstrilla, Cymbasoma.

DIAS, C.O., MEDEIROS, G.F. \& BONECKER, S.L.C. 2008. Novas ocorrências para Monstrilloida Sars, 1901 (Crustacea: Copepoda) do Rio Grande do Norte (costa nordeste do Brasil). Biota Neotrop. 8(2): http:// www.biotaneotropica.org.br/v8n2/pt/abstract?short-communication+bn01508022008.

Resumo: Durante uma série de amostragens de zooplâncton, realizadas durante o ano de 1984, na costa sul do estado do Rio Grande do Norte, Brasil, um total de 50 exemplares de copépodes Monstrilloida foram coletados. Os exemplares pertencem a quatro espécies (Monstrilla brasiliensis Suárez-Morales \& Dias, Cymbasoma cf. longispinosum, Cymbasoma cf. rigidum and Cymbasoma gracilis Gurney). Os complexos taxonômicos formados pelas espécies $C$. cf. longispinosum e $C$. cf. rigidum em águas brasileiras são discutidos. Os comprimentos totais dos exemplares são fornecidos com a finalidade de contribuir com futuros estudos e revisões dos espécimes pertencentes a estes complexos de espécies. A espécie Monstrilla brasiliensis foi coletada pela primeira vez na região costeira do estado do Rio Grande do Norte, expandindo a sua distribuição geográfica na costa nordeste brasileira. Os resultados apresentados aumentam a quatro o número de espécies de Monstrilloida conhecidas para a costa do estado do Rio Grande do Norte.

Palavras-chave: zooplâncton, copépodes, atlântico sudoeste, costa brasileira, Monstrilla, Cymbasoma. 


\section{Introduction}

Out of the eleven orders currently recognized in the subclass Copepoda (Huys \& Boxshall 1991, +Thaumatopsylloida see Ho et al. 2003), the Monstrilloida is one of the least known. Currently, there are four genera recognized as valid: Monstrilla Dana, Monstrillopsis Sars, Cymbasoma Thompson and Maemonstrilla Grygier \& Ohtsuka (Huys \& Boxshall 1991, Grygier 1994a, Suárez-Morales \& Gasca, 2004, Grygier \& Ohtsuka 2008). Monstrilloids have non-feeding, free-swimming adults that lack appendages between the antennules and swimming legs (Grygier \& Ohtsuka 2008). Their endoparasitic larvar are known from an increasingly diverse assortment of benthic macroinvertebrates such as polychaetes, mollusks and other invertebrates (Davis 1984, Grygier \& Ohtsuka 2008). This order is generally quite scarce, with many species being known from only one or a few specimens (Suárez-Morales et al. 2006). Adults are frequently captured by plankton nets from coastal-neritic systems at all latitudes (Suárez-Morales \& Dias 2001a, Suárez-Morales \& Ivanenko 2004).

Until now, the majority of the occurrence of the monstrilloid copepod in the northeastern Brazilian coast (Rio Grande do Norte, Paraíba and Pernambuco states) are formed by dissertations (Pekala 1981, Silva 1994, Silva 1999, de Almeida 2006) and theses (Gusmão 2000, Porto Neto 2003) to order and genera levels. Previous surveys of the monstrilloid fauna from northeastern Brazil (Rio Grande do Norte, Pernambuco, Alagoas and Bahia states) yielded records of Monstrilla grandis Giesbrecht 1891, M. rugosa Davis 1947, Cymbasoma cf. rigidum Thompson 1888, C. cf. longispinosum Bourne 1890, C. gracilis Gurney 1927, and C. quadridens Davis 1947; also, four new species were described (Suárez-Morales \& Dias 2000, Suárez-Morales \& Dias 2001b). Cymbasoma cf. longispinosum, $C$. cf. rigidum and $C$. gracilis were collected also in the coastal region off Rio Grande do Norte (Dias \& Bonecker 2007a).

As part of serial surveys of the marine crustacean fauna of the coast of Rio Grande do Norte, zooplankton samples were collected in two coastal areas, from January through June 1984. Among these samples several specimens of monstrilloid copepods were obtained and sorted for identification. The aim of this study was to expand the knowledge of the composition and distribution of the monstrilloid copepods in the region.

\section{Material and Methods}

The sampling plan was carried out during 1984, from January through June, along profiles perpendicular to the coast, at eight sites along the South coast of Rio Grande do Norte as far as the $30 \mathrm{~m}$ isobath. The two sites positive for Monstrilloida were Tabatinga $\left(6^{\circ} 04^{\prime} 00^{\prime \prime} \mathrm{S}\right.$ and $\left.35^{\circ} 06^{\prime} 00^{\prime \prime} \mathrm{W}\right)$ and Tibau do Sul (6 $6^{\circ} 10^{\prime} 60^{\prime \prime} \mathrm{S}$ and $35^{\circ} 04^{\prime} 60^{\prime \prime} \mathrm{W}$ ), (Figure 1).

Three sampling stations were located in each profile at the isobaths of 10, 20 and $30 \mathrm{~m}$. In each station, two samples were collected during the day: one by subsurface horizontal and the other by vertical hauls with a conical plankton net (mesh size: $250 \mu \mathrm{m}$, mouth diameter: $60 \mathrm{~cm}$ ). Samples were fixed and preserved in $4 \%$ buffered formalin. The monstrilloid copepods were sorted out from the original samples.

All specimens were deposited in the zooplankton collection of the Integrated Zooplankton and Ichthyoplankton Laboratory of the Federal University of Rio de Janeiro (MONSTRILLOIDA DZUFRJ). The individuals were measured from the anterior end of the cephalic somite to the posterior margin of the anal somite.

\section{Results and Discussion}

Of a total of the 72 samples collected in Tabating and Tibau do Sul profiles, six samples were positive for Monstrilloida. A total

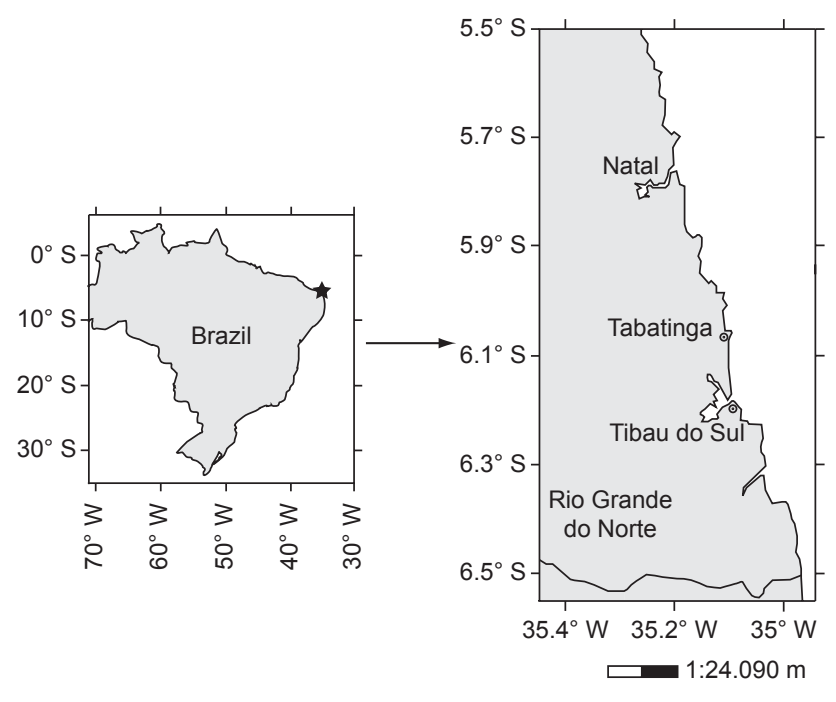

Figure 1. Map of the study area indicating the sampling stations with the occurrence of monstrilloids.

Figura 1. Mapa da área de estudo indicando as estações de amostragem com a ocorrência de Monstrilloida.

of 50 adult individuals of monstrilloid copepods were obtained; they were found to belong to four species: Monstrilla brasiliensis Suárez-Morales \& Dias 2000, Cymbasoma gracilis Gurney 1927, Cymbasoma cf. longispinosum Bourne 1890 and Cymbasoma cf. rigidum Thompson 1888.

A single female of Monstrilla brasiliensis $(2.02 \mathrm{~mm})$ was collected (MONSTRILLOIDA DZUFRJ 207) (Table 1). This species had a total length similar to that found by Suárez-Morales \& Dias (2000) from specimens collected from the northeastern (state of Bahia) and central coasts (states of Espírito Santo and Rio de Janeiro) of Brazil, which ranged from 1.77 to $3.01 \mathrm{~mm}$. This is the second record of the species at the Brazilian northeastern coast, and the first from the Rio Grande do Norte coast. The occurrence of M. brasiliensis in the area allows a northwards expansion of its known distributional range.

Twenty-six females of Cymbasoma gracilis (0.90-1.97 mm) were collected (MONSTRILLOIDA DZUFRJ 113 to 115) (Table 1). The length of these specimens is within the range found on specimens from the northeastern coast (state of Bahia), but smaller than those found by Dias \& Bonecker (2007a, b) off central and south coast of Brazil $(1.30-2.60 \mathrm{~mm})$. This species has been recorded from tropical waters of the Atlantic and Indian oceans and in the Mediterranean and Red seas, with a length range of 1.4 to $2.3 \mathrm{~mm}$ (Gurney 1927, Isaac 1975). Dias \& Bonecker (2007a) marked the local distributional range of this species as from the northeastern (states of Bahia and Rio Grande do Norte) to the southern Brazilian coast (state of Paraná).

Five specimens of Cymbasoma cf. longispinosum (three females, two males, one damaged) with total body lengths ranging from 1.28 to $2.01 \mathrm{~mm}$ (females) and $0.68 \mathrm{~mm}$ (male) (Table 1), and eighteen males (two damaged) of Cymbasoma cf. rigidum (0.52-1.13 mm) (Table 1), were also recorded (Cymbasoma cf. longispinosum MONSTRILLOIDA DZUFRJ 172 to 173 and Cymbasoma cf. rigidum MONSTRILLOIDA DZUFRJ 80 to 82). Cymbasoma cf. longispinosum and $C$. cf. rigidum were found to be distributed from off northeastern (state of Rio Grande do Norte) to 
Table 1. Total number, total length $(\mathrm{mm})$ and temperature values $\left({ }^{\circ} \mathrm{C}\right)$ of the site with occurrence of monstrilloid copepods from coastal region of the Rio Grande do Norte.

Tabela 1. Número total de organismos, comprimento total ( $\mathrm{mm})$ e valores de temperatura $\left({ }^{\circ} \mathrm{C}\right)$ das localidades com ocorrência de copépodes Monstrilloida coletados na região costeira do Rio Grande do Norte.

\begin{tabular}{lccc}
\hline \multicolumn{1}{c}{ Species } & $\begin{array}{c}\text { Total } \\
\text { Number }\end{array}$ & $\begin{array}{c}\text { Total } \\
\text { length }\end{array}$ & Temperature \\
\hline Monstrilla brasiliensis & 1 & 2.02 & 27.0 \\
Cymbasoma gracilis & 26 & $0.90-1.97$ & $23.3-25.9$ \\
$\begin{array}{l}\text { Cymbasoma } \text { cf. } \\
\text { longispinosum (female) }\end{array}$ & 3 & $1.28-2.01$ & $22.8-25.5$ \\
$\begin{array}{l}\text { Cymbasoma } \text { cf. } \\
\text { longispinosum (male) }\end{array}$ & 2 (1 damage) & 0.68 & $22.8-25.5$ \\
Cymbasoma cf. rigidum & 18 & $0.52-1.13$ & $20.5-22.8$ \\
\hline
\end{tabular}

southern Brazil (Dias 1996, Johnsson 1998, Duarte 1999, Dias \& Bonecker 2007a, b).

There are no morphological differences between the specimens found in the present study and the specimens designated as C. cf. longispinosum and the males of $C$. cf. rigidum by Dias (1996), although the lengths differ from values reported by Dias (1996), Dias $\&$ Bonecker (2007b) and Duarte (1999) for other Brazilian specimens. The largest specimens of $C$. cf. longispinosum were found off central and south Brazil (females: $3.10 \mathrm{~mm}$, males: $2.00 \mathrm{~mm}$ ), the same was true for males of $C$. cf. rigidum (up to $1.62 \mathrm{~mm}$ ). Leite et al. (2007) found males and females of $C$. longispinosum in a tropical Amazon estuary in northern Brazil. This occurrence expands the knowledge of their distributional range. The authors reported that the total length of specimens in northern Brazil was shorter than those observed in studies carried out at the south and southeast of Brazil. The different lengths among the Brazilian specimens can be attributed to the influence of temperature. Hopcroft et al. (2001) related increases of the copepod size with decreasing temperature and with depth into oceanic waters. During the sampling of these species the temperatures registered ranging from 20.5 to $27.0^{\circ} \mathrm{C}$ (Table 1). These temperatures are superior to the ones found at the south and southeast of Brazil by Dias \& Bonecker (2007a).

Although Isaac (1975) reported the distribution of the species C. longispinosum and $C$. rigidum to be worldwide, some authors consider that these are actually species-complexes, and that the strict forms have a more limited distributional range (Grygier 1994b, Suárez-Morales 2006). Dias and Bonecker (2007b) discussed the problem of the taxonomic complexes formed by the species $C$. cf. longispinosum and $C$. cf. rigidum in Brazilian waters. The wide distribution reported for these species could certainly be a result of overlooking closely related species. Because of this problem, in the present report the specimens of $C$. cf. longispinosum and $C$. cf. rigidum are regarded as probable members of taxonomic complexes formed by the nominal species $C$. longispinosum and C. rigidum; but they might be undescribed taxa (Dias \& Bonecker 2007b). This fact could explain the different lengths found in the Brazilian specimens in relation to figures reported from other localities. Rose (1933) and Sars (1921) reported larger lengths (F: 2.3 to $3.16 \mathrm{~mm}$, M: 1.8 to $2.3 \mathrm{~mm}$ ) for C. longispinosum, and Wilson (1950) and Rose (1933) reported different sizes (1.5 to $1.8 \mathrm{~mm}$ ) for males of $C$. rigidum. Although the size variation within a species may result from differences in the size of the host and the number of individuals within a host (Suárez-Morales 2000), the lengths of the specimens are provided in order to contribute to future studies and revisions of the specimens belonging to these species-complexes in the Brazilian coastal waters.

The addition of Monstrilla brasiliensis in this report increases to four the number of species of Monstrilloida known from the Rio Grande do Norte region. The occurrence of these species expanded the distribution proposed by Dias \& Bonecker (2007a) of the associations of tropical species in Brazilian coast, characterized by the presence of tropical water (temperatures $>18.5^{\circ} \mathrm{C}$ and salinities > 36.0). Because of their scarcity in the zooplankton samples, the value of the occurrence of each specimen is high.

\section{Acknowledgements}

This study was conducted in the Laboratório Integrado de Zooplâncton e Ictioplâncton, Departamento de Zoologia, Instituto de Biologia, Universidade Federal do Rio de Janeiro (UFRJ) and Departamento de Oceanografia e Limnologia, Centro de Biociências, Universidade Federal do Rio Grande do Norte (UFRN). It is part of a Lobster Project (SUDENE/CIRM/UFRN/UFPE).

\section{References}

ALMEIDA, L.R. 2006. Avaliação Espaço-Temporal do Zooplâncton da Laguna Estuarina de Guaraíras, RN, Brasil. Dissertação de Mestrado, Universidade Federal do Rio Grande do Norte, Natal.

DAVIS, C.C. 1984. Planktonic Copepoda (including Monstrilloida). In Marine plankton life cycle strategies (K.A. Steidinger \& L.M. Walter, eds.). CRC Press, Boca Raton, Florida, p. 67-91.

DIAS, C.O. 1996. Monstrilloida (Copepoda) off the Brazilian coast. Hydrobiologia 324(3):253-256.

DIAS, C.O \& BONECKER, S.L.C. 2007a. Study of Monstrilloida distribution (Crustacea: Copepoda) in the Southwest Atlantic. Panamjas 2(3):270-278.

DIAS, C.O \& BONECKER, S.L.C. 2007b. New records of Monstrilloida Sars, 1901 (Crustacea: Copepoda) on the Brazilian northeastern coast. Biota Neotrop. 7(2): http://www.biotaneotropica.org.br/v7n2/pt/ fullpaper?bn00407022007+en (último acesso em 04/18/2008).

DUARTE, A.K. 1999. Ocorrência de Monstrilloida (Copepoda) em águas costeiras do Sul do Brasil. Nauplius 7:201-202.

GRYGIER, M.J. 1994a. Identity of Thaumatoessa (= Thaumaleus) typica Krøyer, the first described monstrilloid copepod. Sarsia 78(3-4):235-242.

GRYGIER, M.J. 1994b. Nomenclature, redescription, and new record from Okinawa of Cymbasoma morii Sekiguchi, 1982 (Monstrilloida). In Ecology and Morphology of Copepods. Developments in Hydrobiology 102 (F.D. Ferrari \& B.P. Bradley, eds.). Hydrobiologia 292-293:23-29.

GRYGIER, M.J. \& OHTSUKA, S. 2008. A new genus of monstrilloid copepods (Crustacea) with anteriorly pointing ovigerous spines and related adaptations for subthoracic brooding. Zool. J. Linn. Soc. 152(3):459-506.

GURNEY, R. 1927. VIII. Report on the Crustacea Copepoda and Cladocera of the plankton. Trans. Zool. Soc. Lond. 22(2):139-171.

GUSMÃO, L.M.O. 2000. Comunidade zooplanctônica nas províncias neríticas e oceânicas do estado de Pernambuco - Brasil (Lat 7 32,98' a $08^{\circ} 41,51^{\prime} \mathrm{S}$ Long $34^{\circ} 04,47^{\prime}$ a $\left.35^{\circ} 01,51^{\prime} \mathrm{W}\right)$. Tese de Doutorado, Universidade Federal de Pernambuco, Recife.

HO, J.S., DOJIRI, M., HENDLER, H. \& DEETS, G.B. 2003. A new species of Copepoda (Thaumatopsyllidae) symbiotic with a brittle star from California, USA, and designation of a new Order Thaumatopsylloida. J. Crust. Biol. 23(3):582-594.

HOPCROFT, R.R., ROFF, J.C. \& CHAVEZ, F.P. 2001. Size paradigms in copepod communities: a re-examination. In Proceedings of the Seventh International Conference on Copepoda. Developments in Hydrobiology 156 (R.M. Lopes, J.W. Reid \& C.E.F. Rocha, eds.). Hydrobiologia 453-454:133-141. 
HUYS, R. \& BOXSHALL, G.A. 1991. Copepod evolution. The Ray Society, London.

ISAAC, M.J. 1975. Copepoda. Sub-order Monstrilloida. Fiches d'Identification du Zooplancton, Conseil International pour l'Exploration de la Mer, 144-145:1-10.

JOHNSSON, R. 1998. Maxillopoda: Copepoda: Monstrilloida. In Catalogue of Crustacea of Brazil (P.S. Young, ed.). Museu Nacional. Série Livros 6:261-262.

LEITE, N.R., SILVA, J.G., PINHEIRO, S.C.C., CAJUEIRO, L., ABRUNHOSA, F. \& PEREIRA, R.M.C.C. 2007. Occurrence and distribution of Cymbasoma longispinosum (Copepoda: Monstrilloida) in Curuçá Estuary (Northern Brazil). In Plankton Symposium IV, 2007, João Pessoa. Journal of Biology BDUA 2:88. http://planktonsymposium.web. ua.pt/AfPR\%20Site\%2001.06.2006/AfPR\%20Site/PLANKTON\%20 SYMPOSIUM/PSIV\%20Site/BDUA\%20PS\%20IV\%20Abstracts\%20 2007.pdf (último acesso em 06/19/2008).

PEKALA, G.A. 1981. Distribuição espacial e flutuação anual dos copépodos (Crustacea) no estuário do Rio Paraíba do Norte, Paraíba, Brasil. Dissertação de Mestrado, Universidade Federal de Santa Catarina, Florianópolis.

PORTO-NETO, F.F. 2003. Zooplankton as Bioindicator of Environmental Quality in the Tamandaré Reef System, Pernambuco, Brazil: Anthropogenic Influences and Interaction with Mangroves. Doctoral thesis, Universitat Bremen, Bremen.

ROSE, M. 1933. Faune de France 26. Copépodes pelagiques. Fédération Française des Sociétés de Sciences Naturelles. Office Central de Faunistique, Paris.

SARS, G.O. 1921. An account of the Crustacea of Norway with short descriptions and figures of all the species. vol.7. Copepoda Monstrilloida \& Notodelphyoida. The Bergen Museum, Bergen.

SILVA, T.A. 1994. Variação nictemeral e sazonal do zooplâncton no estuário do rio Capibaribe, Recife, Pernambuco, Brasil. Dissertação de Mestrado, Universidade Federal de Pernambuco, Recife.

SILVA, A.C.C. 1999. Estudo Quali-Quantitativo do Zooplâncton no Complexo Estuarino-Lagunar, Guaraíra, RN com ênfase no Filo Chaetognatha. Dissertação de Mestrado, Universidade Federal do Rio Grande do Norte, Natal.
SUÁREZ-MORALES, E. 2000. Taxonomic report on some monstrilloids (Copepoda: Monstrilloida) from Toulon Bay, France. Bull. Inst. R. Sci. Nat. Belg. 70:107-118.

SUÁREZ-MORALES, E. 2006. Validation and redescription of Cymbasoma germanicum (Timm) (Crustacea: Copepoda: Monstrilloida) from Helgoland with comments on C. rigidum Thompson. Helgol. Mar. Res. 60(3):171-179.

SUÁREZ-MORALES, E. \& DIAS, C.O. 2000. Two new species of Monstrilloida (Copepoda) from Brazil. J. Mar. Biol. Ass. U.K. 80(3670):1-9.

SUÁREZ-MORALES, E. \& DIAS, C.O. 2001a. A new species of Monstrilla (Copepoda: Monstrilloida) from Brazil with notes on M. brevicornis Isaac. Proc. Biol. Soc. Wash. 114(1):219-228.

SUÁREZ-MORALES, E. \& DIAS, C.O. 2001b. Taxonomic report of some monstrilloids (Copepoda: Monstrilloida) from Brazil with description of four new species. Bull. Inst. R. Sci. Nat. Belg. 71:65-81.

SUÁREZ-MORALES, E. \& GASCA, R. 2004. On the invalidity of Strilloma Isaac (Copepoda: Monstrilloida): observations from the type species. Zool. Stud. 43(2):292-299.

SUÁREZ-MORALES, E. \& IVANENKO, V.N. 2004. Two new species of Monstrillopsis Sars (Crustacea: Copepoda: Monstrilloida) from the White Sea and Norway, with comments on M. dubia Scott. Arctic 57(1):37-46.

SUÁREZ-MORALES, E., BELLO-SMITH, A. \& PALMA, S. 2006. A revision of the genus Monstrillopsis Sars (Crustacea: Copepoda: Monstrilloida) with description of a new species from Chile. Zool. Anz. 245(2):95-107.

THOMPSON, I.C. 1888. Copepoda of Madeira and the Canary Islands, with descriptions of new genera and species. J. Linn. Soc. London (Zool.) 20:145-156.

WILSON, C.B. 1950. Contributions to the biology of the Philippine Archipelago and adjacent regions. Copepods gathered by the United States Fisheries Steamer 'Albatross' from 1887 to 1909, chiefly in the Pacific Ocean. Bull. U.S. Nat. Mus. 100(14,4):141-441.

Data Received 14/11/07 Revised 04/04/08 Accepted 05/05/08 